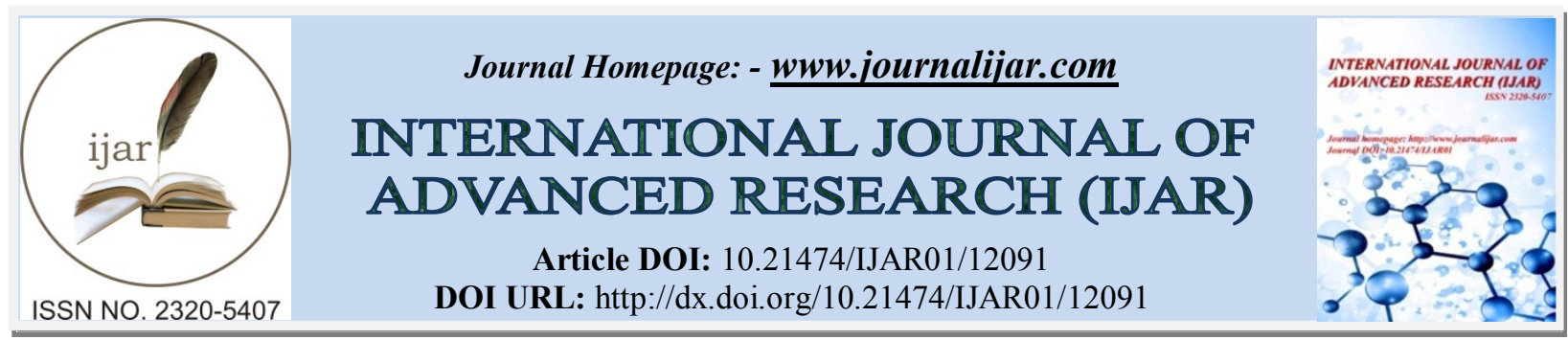

RESEARCH ARTICLE

\title{
QUANTITATIVE ASSESSMENT OF THE RISK RELATED TO THE INGESTION OF METALS DUE TO THE CONSUMPTION OF WELL WATER (IN COTE D'IVOIRE)
}

\author{
Kouadio Enika Floresse, Yoboué Behibolo Antoinette, Akmel Djedjro Clement and Assidjo Nogbou \\ Emmanuel
}

Laboratoire des Procèdes Industriels, de Synthèses, de l'Environnement et des Energies Nouvelles, Institut National Polytechnique Felix Houphouët Boigny, (INP-HB), BP 1093 Yamoussoukro, Cote d'Ivoire.

\section{Manuscript Info}

Manuscript History

Received: 25 September 2020

Final Accepted: 28 October 2020

Published: November 2020

Key words:-

Assessment, Risk, Heavy Metals, Ingestion, Well Water

\begin{abstract}
Well water is a source of supply in urban areas when there is a shortage of water from the public water system. This water doses not undergo any treatment, so its consumption could expose consumers to health risks. The aim is to estimate the chemical risk related to the ingestion of heavy metals contained in the well water consumed by the population. To achieve this objective, a socio-demographic survey was carried out among 600 people.Subsequently, 270 well water samples were collected from 7 localities.The risk assessment was carried out according to the Codex Alimentarius method, (2007) using Monte Carlo simulation. This simulation indicates that for every 100,000 inhabitants, about 1650 to 6020 individuals would observe the risk related to the ingestion of lead contained in the well water of San Pedro, Daloa and Abidjan.The results indicate that the risk related to the ingestion of arsenic to due the consumption of these waters is $1.75 \%$ and $4.2 \%$ respectively in the cities of San-Pedro and Abidjan. That is to say, 1750 to 4200 individuals who would probably suffer from cancer out of 100,000 people exposed to the consumption of well water from these study areas. In short, the consumption of well water would constitute a health risk for the consumer.
\end{abstract}

Copy Right, IJAR, 2020,. All rights reserved.

\section{Introduction:-}

Access to drinkable water is a prerequisite for improving people's living conditions.For this reason, for years, Ivory Coast in particular has been committed to the promotion of drinkable water supply (Koukougnon, 2015).However, despite the progress recorded and the efforts made to improve this sector, the WHO and UNICEF report (2017) estimates that more than 4 million people still face problems of access to drinkable water.In order to fight against the problems of potable water supply, part of the populations of these cities still use water from traditional wells for domestic needs.However, well water quality studies conducted by authors in Ivory Coast, including Sangaré et al (2016), Konan et al (2017) and Ahoussi et al (2018), have revealed the presence of trace metal elements in well water used for domestic purposes.However, the ingestion of these pollutants can cause health problems (Kamilou et al. 2014). These authors assessed the risk of heavy metal ingestion following the consumption of well water using the qualitative approach. It would be imperative to use the quantitative approach to risk which is nowadays, much used successfully in developed countries to manage microbiological, chemical and environmental risks. This approach provides a numerical value for the risk of the hazard to which the population would be exposed.The

Corresponding Author:- Kouadio Enika Floresse

Address:- Laboratoire des Procèdes Industriels, de Synthèses, de l'Environnement et des Energies Nouvelles, Institut National Polytechnique Felix Houphouët Boigny, (INP-HB), BP 1093

Yamoussoukro, Cote d'Ivoire. 
objective of this study is to estimate the levels of health risks to which consumers are exposed as a result of the ingestion of metals contained in well water.

\section{Material and methods:-}

\section{Presentation of the study area}

The assessment of risks related to the ingestion of heavy metals ( $\mathrm{Pb}, \mathrm{Cd}$ and $\mathrm{As})$ due to the consumption of well water discussed in this study focused on well water from seven localities in Ivory Coast. These cities were selected from the main regions : Abidjan (South), Abengourou (South-East), Bouaké (Center), Korhogo (North), Daloa (Center-West), Man (West), and San-Pedro (South-West) (Fig.1).

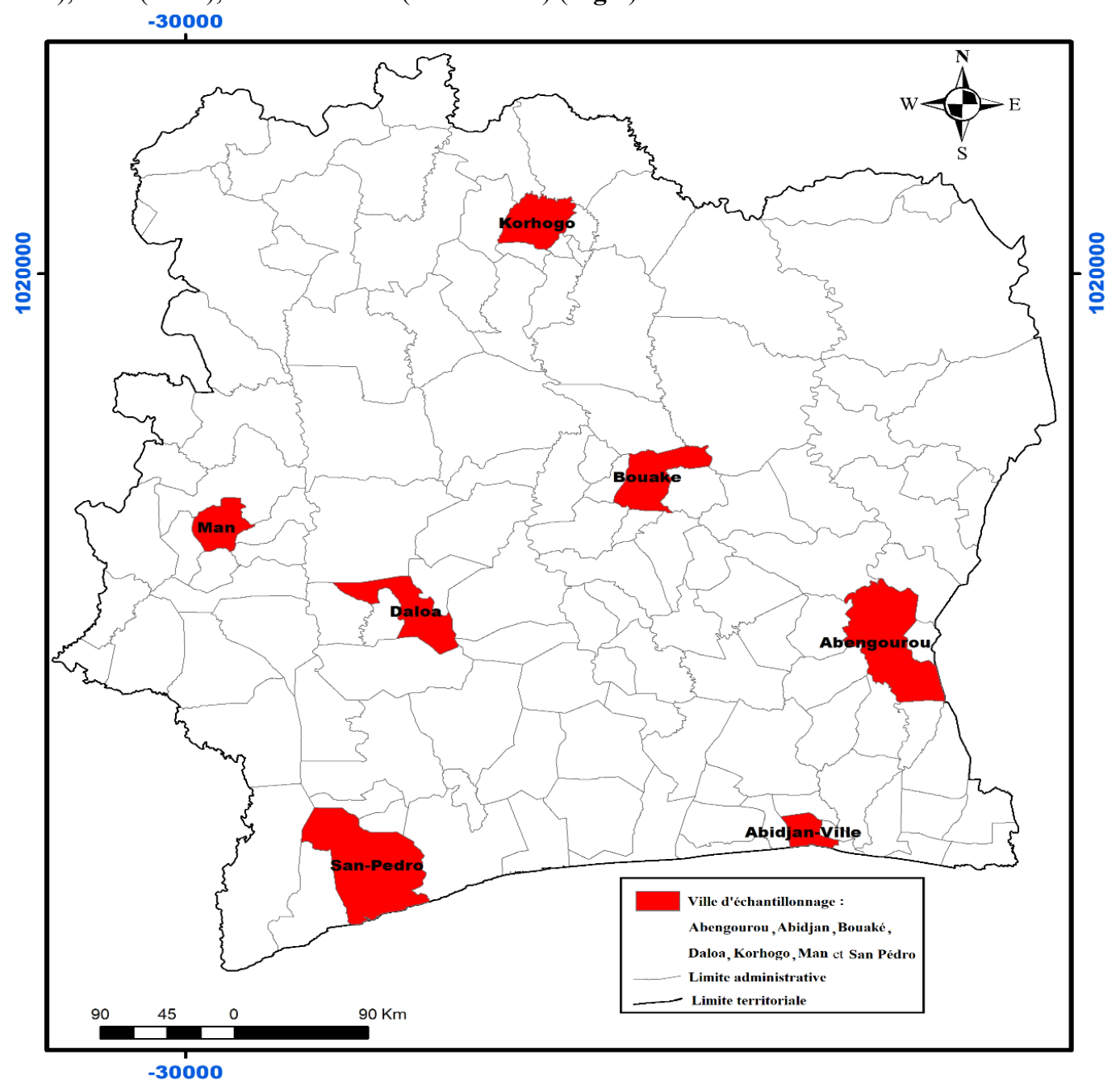

Figure 1:- Study areas of seven localities in Ivory Coast.

\section{Investigation}

In order to collect information on water sources, the amount of water ingested per person per day, the fréquence of water consumption and the body mass of individuals, a Survey was conducted in the cities selected for the study (Figure 1).To this end, a semi-directive questionnaire was developed based on a qualitative analysis of the population. The survey period ran from December22, 2017 to August 28, 2018.

\section{Sizes of the population to be surveyed}

To determine the number of people who participated in the survey, the systematic random sampling technique of (Giezendanner, 2012) was used with the following statistical formula expression.

$\mathrm{n}=\frac{\boldsymbol{t}^{2} \boldsymbol{x}[\boldsymbol{P} x(1-P)]}{\boldsymbol{e}^{2}}$ Equation (1)

$\mathrm{n}$ :minimum size of the persons to be investigated 
e: margin of error

$\mathrm{t}$ : margin coefficient deducted from the confidence rate

$\mathrm{p}$ : proportion of items in the parent population that have a given property Thus, the conventional value of each element of this fraction is as follows:

t: 1. 96; p: 0,5 and e: 0.05 .

The number of people selected in each city was proportional to its demographic size (quota sampling). The minimum size of the number of people to be surveyed, using equation 1 , is therefore 384.16 . In the case of this study, the size of respondents was extrapolated to 600

\section{Sampling}

The sampling campaign was conducted from January 17 to May 28, 2018. A total of 270 well water samples (30 samples for each of the cities of Korhogo, Bouaké, Daloa, Man, Abengourou, San-Pedro and 60 samples for the city of Abidjan) were collected in these different localities.Before the sampling campaign, the labelled material was thoroughly washed, rinsed with distilled water and then washed and rinsed again. The samples were taken using a sump. The water collected was then transferred to polyethylene bottles with a capacity of $1000 \mathrm{~mL}$. The water samples for mineral analysis were acidified with concentrated sulfuric acid at $(98 \%)$ to obtain a $\mathrm{pH}<2$. They were then put out of the light in coolers containing ice to maintain the temperatures at $4^{\circ} \mathrm{C}$ until they reached the laboratory.

\section{Analysis of chemical parameters}

Heavy metals were determined by atomic absorption spectrometry (AAS) with an air-acetylene flame, type Varian AA20 according to the Afnor NFT 90-112 standard.

\section{Quantitative risk assessment}

Quantitative health risk assessment is a method for estimating by calculation the health risks to a population exposed to contamination of food or water. The assessment of health risks related to the ingestion of lead, arsenic and cadmium from the consumption of well water will follow four main steps (Codex Alimentarius, 2007).

\section{Hazard identification}

Hazard identification allows the selection of substances to be taken into account in the quantitative health risk assessment (QHRA) and to identify the effects that can be derived from them. In the case of this study the selected hazards are: arsenic, cadmium and lead.

\section{Hazard characterization}

This step consists of establishing the dose response relationship. The purpose of the dose-response relationship is to define a quantitative relationship between the dose administered or absorbed and the incidence of the effect, from which the Toxicological Reference Value (TRV) or Reference Dose (RfD) is established. In this study, the TRV used are those published by the Institut National de l'Environnement et des Risques (INERIS; 2012; 2014). For chronic threshold effects, the ATSDR (Agency for Toxic Substances and Disease Registry).

\begin{tabular}{|l|l|}
\hline Hazard & Tolerated Daily Dose (TDI) \\
\hline Arsenic & $3.10^{-4} \mathrm{mg} / \mathrm{kg} / \mathrm{j}$. \\
\hline Cardium & $2.10^{-4} \mathrm{mg} / \mathrm{kg} / \mathrm{j}$ \\
\hline Plomb & $3.6 .10^{-3} \mathrm{mg} / \mathrm{kg} / \mathrm{j}$. \\
\hline
\end{tabular}

Table I:- Toxicological Reference Value.

\section{Exposure assessment}

According to the Codex Alimentarius definition, exposure estimation is a quantitative and/or qualitative assessment of the likely absorption of hazards (biological, chemical, physical) from food or water. It consists of quantifying the level of chemicals, microorganisms or toxins in human populations, population subgroups and individuals who are exposed, in terms of magnitude, duration and frequency.In this work, the exposure assessment consisted of determining the quantities of heavy metals (lead, arsenic and cadmium) ingested following the consumption of well water. To define this exposure, the distribution of the quantity of water ingested (Q), the distribution of the concentration of arsenic and lead $(\mathrm{C})$, the distribution of the frequency of water consumption $(\mathrm{F})$ and the distribution 
of body weight $(\mathrm{P})$ were determined. These variables were obtained from a survey and chemical analyses. Thus, the exposure estimate was determined according to the following expression :

$\mathrm{I}=\mathrm{QXC} X \frac{\mathrm{F}}{\mathrm{PC}}$ equation (2)

I: daily dose of exposure

$\mathrm{C}$ : Concentration of metals expressed in $\mathrm{mg} / \mathrm{kg}$;

Q: Amount of water ingested per day, expressed in $\mathrm{mg} /$ day;

$\mathrm{F}$ : Frequency: water is consumed 7 days $/ 7$ days, hence $\mathrm{F}=1$;

P: Body weight of the individual $(\mathrm{kg})$.

Variables C, Q, F and P were sampled by the Bootstrap method. The ingested daily EDI exposure intake of heavy metals as a function of C, Q, F and P was estimated using a Monte Carlo simulation. A total of 1,500 iterations were performed. Each simulation is a numerical calculation corresponding to a possible situation, more or less probable, of a real system. The results of this simulation represent the quantities of heavy metals ingested during the consumption of well water.

Disease risk has been defined as the probability of ingesting the chemical above the Daily Tolerance Dose (DTD). This risk named " $\mathrm{R}$ " is defined as being equal to 1-P. This probability "P" is obtained by projecting the DTD of the chemical substance on the function of the cumulative densities described by the different iterations by Monte Carlo simulation. R "Risk": Proportion of the population likely to become ill from water consumption.

$\mathrm{R}=1-\mathrm{P}$ Equation (3)

$\mathrm{R}$ : Risk of disease occurrence

\section{Risk Characterization}

Integrates the results of hazard identification, characterization and exposure assessment. Based on these results, the risk characterization must quantitatively estimate the severity (that means probability) of the effects.

\section{Statistical analysis}

The Excel 2013 analysis utility and Matlab R2015a software were used to analyze the data collected.

\section{Results And Discussion:-}

Metallic trace elements (arsenic, cadmium and lead).

The average concentrations of different metals in the well water of the study areas are described in figures 2 and 3. The results show that the cadmium concentrations obtained in the well water are below the detection limit of the measuring device. Arsenic contents oscillate between $0 \mu \mathrm{g} / \mathrm{L}$ and $15.8 \pm 0.58 \mu \mathrm{g} / \mathrm{L}$ with a mean value of $7.93 \pm 0.25$ $\mu \mathrm{g} / \mathrm{L}$. The highest average arsenic value was detected in Abidjan well water $(15.8 \pm 0.58 \mu \mathrm{g} / \mathrm{L})$. Concerning lead, the average concentrations detected ranged from $1.5 \pm 0.28 \mu \mathrm{g} / \mathrm{L}$ to $9.5 \pm 0.42 \mu \mathrm{g} / \mathrm{L}$ with a mean value of $6.64 \pm 0.84$ $\mu \mathrm{g} / \mathrm{L}$. How that the cadmium concentrations obtained in the well water are below the detection limit of the measuring device. Arsenic contents oscillate between $0 \mu \mathrm{g} / \mathrm{L}$ and $15.8 \pm 0.58 \mu \mathrm{g} / \mathrm{L}$ with a mean value of $7.93 \pm 0.25$ $\mu \mathrm{g} / \mathrm{L}$. The highest average arsenic value was detected in Abidjan well water $(15.8 \pm 0.58 \mu \mathrm{g} / \mathrm{L})$. Concerning lead, the average concentrations detected ranged from $1,5 \pm 0.28 \mu \mathrm{g} / \mathrm{L}$ to $9.5 \pm 0.42 \mu \mathrm{g} / \mathrm{L}$ with a mean value of $6.64 \pm 0.84$ $\mu \mathrm{g} / \mathrm{L}$. The presence of arsenic and lead in well water could be justified by releases from activities carried out by individuals living near these wells. Indeed, the work of Rasheed et al (2017) and Zhang et al (2019) showed on the one hand that the presence of arsenic and lead in well water would be linked to the release of anthropogenic activities and on the other hand to soil erosion. 


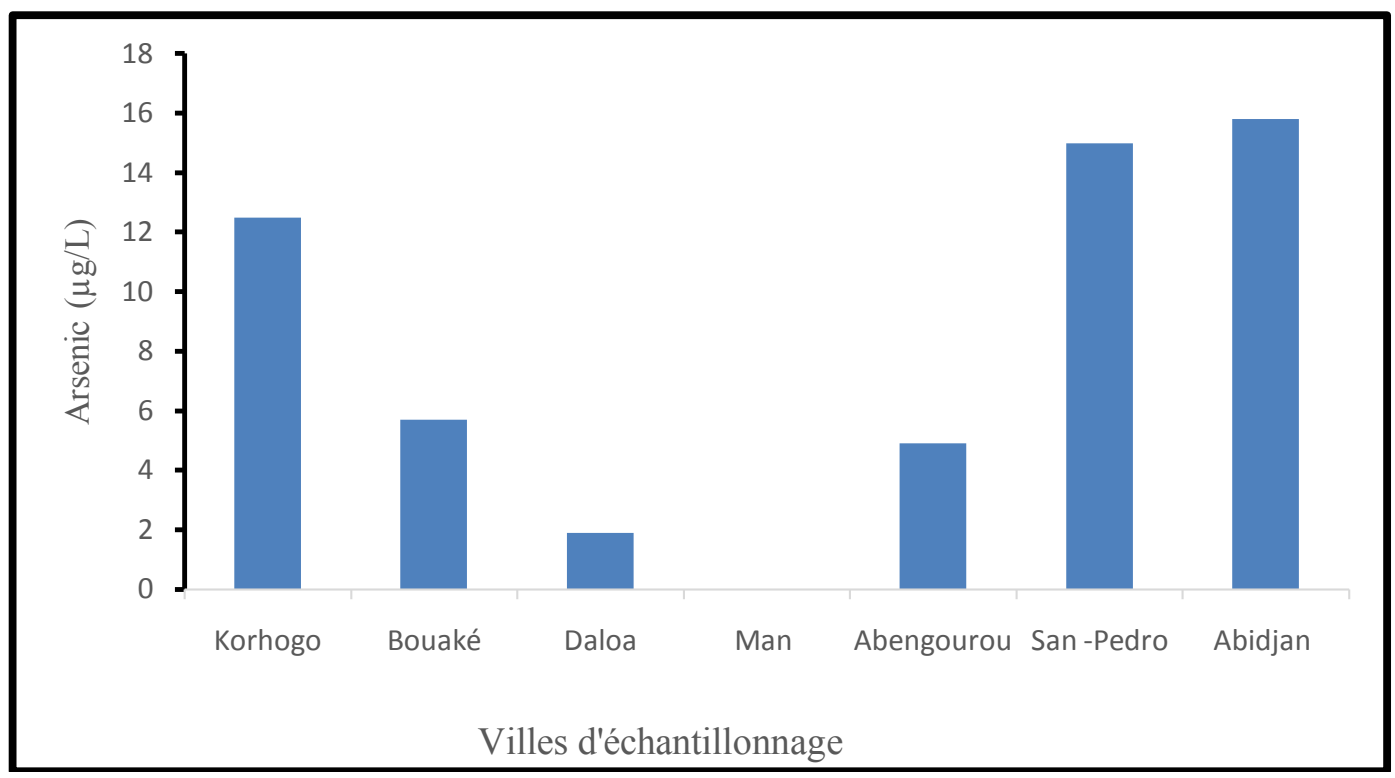

Figure 2:- Average Arsenic Concentration in Study City Well Water.

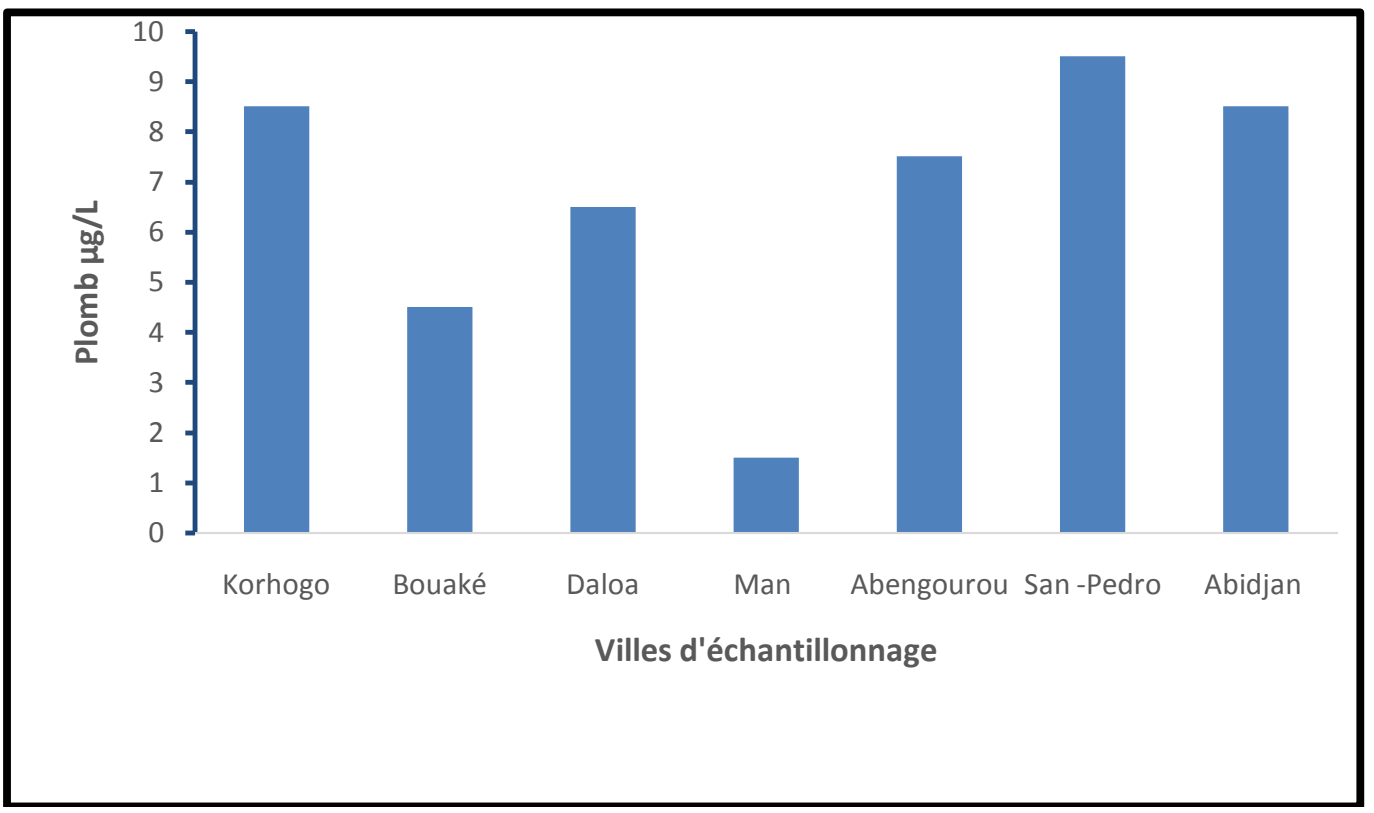

Figure 3:- Average concentration of lead in well water of the studycities.

\section{Assessment of the risk related to the ingestion of lead}

Fig.4A, 4B, and 4C describe the probabilities of ingesting a quantity of lead from well water in the cities of Daloa, San Pedro, and Abidjan. The projection of theDaily Tolerance Dose (DTD) on the cumulative functions, indicates that, the probabilities of ingesting lead at doses less than or equal to the Daily Tolerance Dose (DTD) (3.6 10 ${ }^{-}$ ${ }^{3} \mathrm{mg} / \mathrm{kg} / \mathrm{J}$ ) are $93.99 \%$ (Abidjan), 96.63\% (Daloa) and 98.35\% (San -Pedro). Thus, the probabilities of ingesting lead at doses above the DTD are 1.65\% (San Pedro), 3.37\% (Daloa) and $6.02 \%$ (Abidjan).This shows that, out of 100,000 inhabitants, between 1,650 and 6,020 individuals would be exposed to health problems related to the ingestion of lead contained in well water consumed daily. According to Shaimi et al (2014), lead is a metal that accumulates in various tissues of the body even at low doses. As such, ingestion of lead from well water could expose consumers to health risks. Studies similar to lead exposure conducted by Tanouayi et al. (2015) on groundwater in Togo also revealed daily lead exposure doses above the daily tolerance dose. Exposure to lead during consumption of well water could lead to health problems in adults. For example, Zgheib 2009, Etchevers et al (2017) demonstrated that lead exposure could lead to lead poisoning. Also, Tanouayi et al. 2015, pointed out that 
lead is responsible for abdominal pain, neurological disorders, anemia and high blood pressure in adults. In addition, the Health Canada report (2013) showed that children are particularly susceptible to lead poisoning. The report indicated that lead ingestion in children could lead to anemia, loweredintellectual quotient and neurodevelopmental disorders.
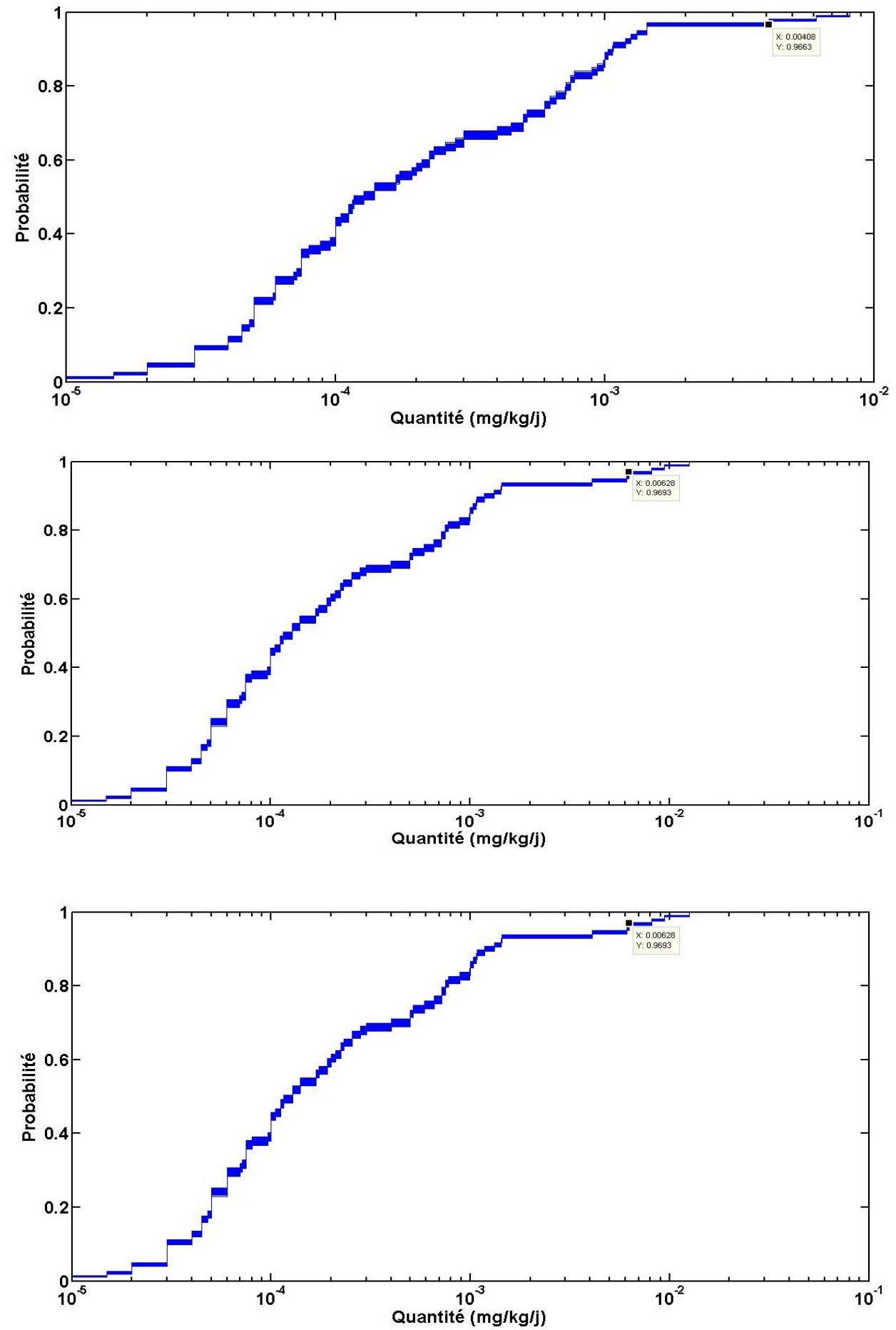

Figure 4:- Risk linked to the ingestion of lead contained in well water according to Monte Carlo type simulation.

\section{Risk assessment of arsenic ingestion}

Figure 5 shows the cumulative density functions describing the probability of arsenic ingestion during well water consumption. The DTD projection on the density functions shows that the probabilities of ingesting arsenic at or 
below the daily tolérance dose $\left(3.10^{-4} \mathrm{mg} / \mathrm{kg} / \mathrm{j}\right)$ is 95.58 (Abidjan) and $98.25 \%$ (San Pedro). On the other hand, the probabilities of ingesting arsenic at doses higher than the daily tolérance dose are 1.75\% (San-Pedro) and $4.42 \%$ (Abidjan). Per 100.000 inhabitants, the risks of arsenic ingestion following consumption of well water are 1750 (San-Pedro) and 4420 (Abidjan). These functions reveal that the populations of Korhogo, Bouaké, Daloa, Man and Abengourou ingest arsenic at doses below the daily tolérance dose.. However, the populations of the cities of San Pedro and Abidjan ingest amounts of arsenic at doses above the daily tolérance dose The probabilities of ingesting arsenic at doses above the Daily Tolerance Dose are $1.75 \%$ in San-Pedro and $4.42 \%$ in Abidjan. It is estimated that per 100,000 inhabitants, about 1750 individuals in San-Pedro and 4420 individuals in Abidjan would observe the risk associated with arsenic ingestion. The presence of arsenic in well water could come naturally from the earth's crust as well as from industrial activities such as the manufacture of pesticides, dyes, and metals (Rasheed et al. 2017). Studies similar to the exposure of arsenic were conducted by Rasheed et al. (2017) showed that doses of arsenic in groundwater above the daily tolerance dose. They stressed that populations consuming arsenic at doses above the Daily Tolerance Dose were exposed to health risks. Thus, the populations of the cities of San Pedro and Abidjan who ingest arsenic at doses higher than the Daily Tolerance Dose are also exposed to health risks. According to Rasool et al (2016), arsenic intoxication is manifested by more or less accentuated gastrointestinal disorders, hepatic and renal disorders and cardiovascular manifestations, hypertension and tachycardia.
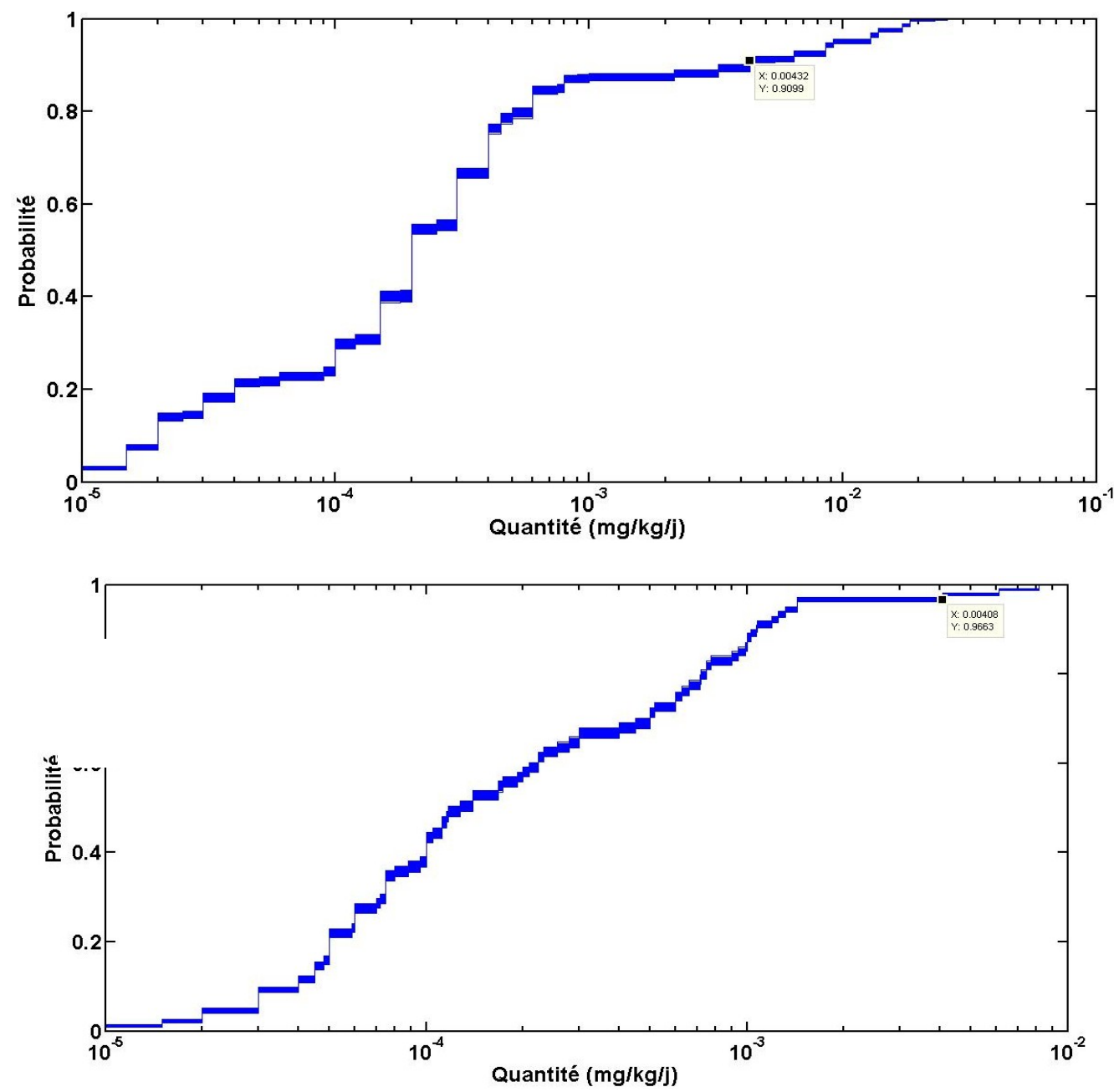

Figure 5:- Risk related to arsenic ingestion according to Monte Carlo simulation.

\section{Conclusion:-}

Simulation using the Monte Carlo method made it possible to estimate the health risk related to heavy metals (lead, arsenic and cadmium) following the consumption of well water in seven localities of the Ivory Coast. The analyses carried out revealed the presence of lead and arsenic in the well water consumed by the populations of these towns. 
This method of data analysis showed that the populations of the towns of Daloa, San-Pedro and Abidjan ingest lead following the consumption of well water at doses higher than the daily tolerance dose. Out of 100,000 inhabitants, the cities of San Pedro, Daloa and Abidjan respectively 1650, 3370 and 6020 of their population would observe risks related to the ingestion of lead.Similarly, the probability of ingesting arsenic at doses above the daily tolerance dose is $1.75 \%$ in San-Pedro and $4.42 \%$ in Abidjan. That is to say, out of 100,000 inhabitants, 1700 individuals in SanPedro and 4200 individuals in Abidjan would be exposed to health problems related to the ingestion of arsenic contained in well water used as drinking water. In sum, the consumption of well water would constitute a health risk for consumers.

\section{References:-}

1. Ahoussi E. K., Keumean N. K, Kouassi M. A. et Koffi B. Y. (2018) :Etude des caractéristiques hydrogéochimiques et microbiologiques des eaux de consommation de la zone périurbaine de la ville de Man : cas du village de Kpangouin (Côte d'Ivoire), International. Journal. Biological. Chemical. Science, 11(6): 3018-3033.

2. Ahoussi K. E., Koffi Y. B., Kouassi A. M., Soro G., Soro N. et Biémi J (2012) : Caractérisation PhysicoChimique et Bactériologique des Ressources en eau des Localités Situées Aux Abords de la Lagune Ébrié dans la Commune de Marcory (District d'Abidjan, Côte d'Ivoire): Cas du Village d'Abia Koumassi. European Journal of Scientific Research, 89 (3):.359-383.

3. Awomon D. F., Coulibaly M., Niamké G. M.et Santos D. S. (2019) :La problématique de l'approvisionnement en eau potable et le développement des maladies à transmission hydrique dans les quartiers d'extension Orly de la ville de Daloa (Côte d'Ivoire), Revue., Espace, Territoires, Sociétés et Santé, 1 (2) : 91 108.

4. Codex Alimentarius Commission. (2007) :Principes et directives pour la gestion des risques microbiologiques. Geneva: Food and Agriculture Organization of the United Nations, World Health Organization, $72 \mathrm{p}$.

5. Diarra A., Dali G.et Sekongo L. G. (2016) :Crise de l'eau potable en milieux urbain : cas de Daloa. Revue géographique de l'Université de Ouaga, 2 :132-142.

6. Etchevers A., Glorennec P., Lucas J. P., Bot B., Camille L. et Le Tertre A. (2017) :Exposition au plomb des enfants en France : niveaux d'imprégnation et déterminants, Toxicologie Analytique et Clinique, 2 : 1-13.

7. Giezendanner (2012) : Taille d'un échantillon aléatoire et Marge d'erreur, CMS-SPIP, http://icp.ge.ch/sem/cms-spip/spip.php, 22p

8. INERIS (2014) :Fiche de données toxicologiques et environnementales des substances chimiques : Cadmium et ses dérivés. DRC-11-117259-10308B.doc. Version N³, 111 p.

9. Kamilou O. S., Hodabalo D. S. Kissao G. I, Komlan M. A., Essô J. B. (2014) :Évaluation et risques sanitaires de la bioaccumulation de métaux lourds chez des espèces halieutiques du système lagunaire togolais. VertigO - revue électronique en sciences de l'environnement, 14 (2) :1-18

10. Konan S. K., Goue D. L., Ohou-Yao M. J., Kouame K.I., Kouassi L. K. et Dongui K.B. (2017) :Qualité chimique des eaux de consommation des populations de la ville de Soubré (sud-ouest, Côte d'Ivoire), International. Journal. Advancd. Research.6(1) : 58-65.

11. Koukougnon W. G. (2015) : Stratégies d'accès à l'eau potable dans un quartier défavorisé: cas de Gobelet dans la commune de Cocody (Abidjan-Côte d'Ivoire), Revue Canadienne de Géographie Tropicale,2 (2) : 60-72.

12. OMS., UNICEF. (2017) : Progrès en matière d'alimentation en eau et d'assainissement : Rapport 2017 : ISBN 978-92-4 251289-2 (Classification NML : WA 670), 116p.

13. Sangare N., Yao K.M. ,kouassi E. K.,.Kouassi N. L. B., Sorom. B., kouassi A. M. (2016). Évaluation de la qualité des ressources en eau près de la décharge urbaine non contrôlée d'Akouédo par le calcul des risques cancérigènes et des indices de pollution, Côte d'Ivoire, Afrique science 12(5) : 279-290 .

14. Shaimi, S., Idrissi, M., Ben Driss, E. et khalil, Bencheikh S. (2014) : Évaluation de l'exposition au plomb autour d'un site industriel contaminé au Maroc. Toxicologie Analytique et Clinique, 26 (2) : 79-86.

15. Tanouayi G., Gnandi K., Ahoudi H. et Ouro-Sama K. (2015) :La contamination métallique des eaux de surface et des eaux souterraines de la zone minière d'exploitation des phosphates de Hahotoe-Kpogame (SudTogo) : cas du cadmium, plomb, cuivre et nickel. Larhyss Journal, $21: 25-40$.

16. Zgheib, S. (2009) :Flux et sources des polluants prioritaires dans les eaux urbaines en lien avec l'usage du territoire, Thèse de Doctorat, Université des Ponts ParisTech, 359 p. 